\title{
Therapeutic help to individuals using and abusing of psychoactive substances
}

\author{
Ajuda terapêutica a indivíduos em uso e abuso de substâncias psicoativas
}

Bárbara Rosa Correia Leandro ${ }^{1}$, Luiz Henrique Batista Monteiro ${ }^{1}$, Roselma Lucchese ${ }^{1}$, Ivânia Vera ${ }^{1}$, Rodrigo Lopes de Felipe ${ }^{1}$, Inaina Lara Fernandes ${ }^{1}$

Objective: to describe the search for the therapeutic help of individuals using and abusing of psychoactive substances. Methods: it is a cross-sectional epidemiology study of individuals from the central-western region of Brazil, with a history of abusive use of psychoactive substances. Face-to-face interviews were conducted at the research sites in a private setting. The data were analyzed by statistical analysis. Results: there were 266 individuals interviewed, $85.3 \%$ were male and with an age of onset of use $\geq 18$ years old. Most interviewees reported seeking help in rehabilitation clinics. Prayer was the most frequent intervention, and the professional with the greatest influence was the pharmacist. Conclusion: men were prevalent among those who sought help, and crack was the drug in use reported by most of them.

Descriptors: Substance-Related Disorders; Nursing; Patient Readmission.

Objetivo: descrever a procura por ajuda terapêutica de indivíduos em uso e abuso de substâncias psicoativas. Métodos: epidemiológico transversal, realizado com indivíduos da região centro-oeste do Brasil, com histórico de uso abusivo de substâncias psicoativas. Realizaram-se entrevistas face a face nos locais da pesquisa em ambiente privativo. Os dados passaram por análise estatística. Resultados: foram entrevistados 266 indivíduos, sendo $85,3 \%$ do sexo masculino e idade de início de uso $\geq 18$ anos. A maioria dos entrevistados relatou busca por ajuda em clínicas de reabilitação. A oração foi a ação de intervenção mais frequente, e o profissional com maior influência foi o farmacêutico. Conclusão: homens foram prevalentes dentre aqueles que procuraram ajuda, e o crack foi a droga em uso relatada pela maioria.

Descritores: Transtornos Relacionados ao Uso de Substâncias; Enfermagem; Readmissão do Paciente.

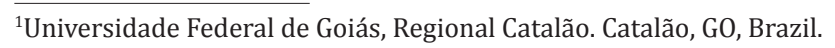

Corresponding author: Ivânia Vera

Av. Dr. Lamartine Pinto de Avelar, 1120, Vila Chaud, CEP: 75704-020. Catalão, GO, Brazil. E-mail: ivaniavera@gmail.com 


\section{Introduction}

World estimates show that 16 to 39 million people have an abusive use of drugs with a range of $3.5 \%$ to $7.0 \%{ }^{(1-2)}$. In the Brazilian context in adolescents, the prevalence is from 0.1 to $4.3 \%$ in the general population and depends on the type of drug used. The most prevalent are marijuana (4.3\%), followed by tranquilizers $(2.5 \%)$ and cocaine $(2.3 \%)$. Among adults, this prevalence ranges from 0.2 to $9.6 \%$, with tranquilizers (9.6\%), marijuana $(6.8 \%)$ and cocaine $(3.8 \%)$ as prevalent $^{(3)}$.

In analogy to the use and abuse of licit psychoactive substances in the adult male population, alcohol consumption $(62.0 \%)$ and tobacco consumption were higher (21.4\%), when compared to the opposite $\operatorname{sex}(12.8 \%)^{(3)}$.

However, drug users (licit or illicit) have been increasingly seeking treatment to cease their use or reduce harm from this habit. From every six people who use drugs worldwide, only two can be treated each year. Men are the largest drug users and women are most susceptible to developing drug addiction ${ }^{(1)}$. Regarding relapses for treatment, men are the ones who seek the most $(60.0 \%)^{(4)}$.

As for the institutions contributing to the treatment of drug users, the Psychosocial Care Center acts as a specialized device to care for these people, encompassing individualized, family and social care. It is a psychosocial model guided by the logic of harm reduction, associated with the level of commitment that individuals have to coexist and/or cease drug use $\mathrm{e}^{(5-6)}$. On the other hand, there are recovery clinics, whose detoxification process adopts methods of sudden stopping of drug use $\mathrm{e}^{(7-8)}$. This service is recognized as a 'therapeutic community' and receives some criticism, as it opposes some principles of the Psychiatric Reform process, by excluding the user from social interaction, and abstinence is the main form of recovery ${ }^{(8)}$.

Therefore, it is questioned how individuals and families involved in alcohol and other drug abuse issues obtain help in the process of rehabilitation and recovery of health and citizenship. This study aimed to describe the search for the therapeutic help of individuals in use and abuse of psychoactive substances to investigate such disquiet.

\section{Methods}

This is a cross-sectional epidemiological study involving individuals who abuse alcohol and other drugs ${ }^{(9)}$. The study was conducted in the Center-West region of Brazil, in an area constituted by a medium-sized municipality. The study site was a public Psychosocial Care Center and six private rehabilitation clinics in chemical dependency denominated "therapeutic communities".

Data were collected from August 2013 to February 2014. Inclusion criteria were individuals aged 18 years old or over, included in the treatment for dependence on licit and/or illicit drugs. Individuals who, at the time of the interview, were sedated and who had an evident state of mental confusion were excluded after a brief physical examination with assessment of the level of consciousness. The interview was conducted individually, face-to-face in a private place with the participants.

In the orientation of the basic number of the sample, the following calculation was performed with statistical power of $80.0 \% \quad(\beta=20.0 \%)$, significance level of $5 \%(\alpha=0.05)$, design effect of 3.0 for an anticipated prevalence of $5.8 \%$ of the most prevalent illicit drug use (marijuana) in the Brazilian population ${ }^{(3)}$. Considering potential losses, the resulting value was 302 individuals who used alcohol and other drugs. It is emphasized that the sampling technique was for convenience, from the spontaneous participation.

A digital instrument was used as a data collection device, developed through Google Docs, which stored the information and generated spreadsheets in 
Microsoft Office Excel for Windows $®$ format.

The pilot test was performed with ten individuals who did not compose the study sample to adjust the questionnaire. The study consisted of socio-demographic data, patterns of alcohol consumption and other psychoactive drugs, the demand for treatment, the therapeutic practices adopted in these places and the professionals involved in the rehabilitation process. The data collection was done by previously qualified interviewers.

The dependent variables consisted of reports of pattern of drug use, divided into three: "use of licit drugs, ULD" ("exclusive consumption of alcohol and tobacco and its derivatives"), "use of illicit drugs UID" (Exclusive use of illegal drugs such as cocaine, marijuana, crack and others prohibited in the Brazilian context) and "use of licit and illicit drugs ULID" (concomitant use of alcohol and tobacco with illicit substances).

The independent variables were the socio-demographic variables: gender, ethnicity, marital status, residing with, children or not, religion, education, income and age of beginning use. Other variables were explored descriptively to characterize drug use and treatment. They are: use and abuse of psychoactive substances considering the most difficult substance to abandon; Time left unused it; Who identified the problem; Age of the first intervention; Uni or multiuser; At least once in life, with the following questions: "alcohol," "crack," "cocaine," "marijuana," and if he was a smoker.

The search for treatment and rehabilitation was described by the variable "search for help for the rehabilitation of individuals using drugs," divided by first, second and third treatment attempts. For the conception about such search, the individuals were evaluated in the interventionist actions performed in the therapeutic communities and the Psychosocial Care Center, listing: prayer, work, group care and practice of more valued or frequent physical activity. Finally, the professionals who influenced the rehabili- tation process, according to the level of satisfaction of the interviewees, were distributed among pharmacist, physician, monitor, occupational therapist, nurse, psychologist, nursing technician, physical educator and social worker.

Data were collected on a digital medium, later arranged in a Microsoft Office Excel for Windows ${ }^{\circledR}$ program spreadsheet and analyzed in the Stata Software Package, version 12.0. Then, they underwent descriptive analysis, guided by the variables described above. For the analysis, the total numbers, frequency and $95 \%$ confidence interval $(95 \% \mathrm{CI})$ were considered. For the quantitative variables, mean, median, minimum and maximum, and standard deviation (SD) were analyzed. For the dependent variables, a Prevalence Ratio (PR) effect measure was applied in a bivariate analysis and those with $\mathrm{p}<0.05$ were considered in the $\chi^{2}$ test.

The study complied with the formal requirements contained in the national and international regulatory standards for research involving human beings.

\section{Results}

The final sample was 266 individuals due to the inconsistency of the questionnaires in 36 participants interviewed. Of them, 266 (33.4\%) were users of licit drugs (alcohol and tobacco), 25 (9.4\%) used only illicit drugs, and 208 (78.2\%) were users of licit and illicit drugs. There were 15 users being part of the public network, and the others (251) were from the private network.

Regarding gender, the sample consisted of most men (228 - 85.3\% CI95\% 80.8-89.8). The mean age was 32.5 (95\% CI 31.38-33.76), median 31.0 (minimum 15 years old, maximum 64 years old), SD of 10.0 years old. Most of them, 173 individuals were from the state in which the data collection took place. The socio-demographic characterization and associated factors are shown in Table 1. 
Table 1 - Bivariate analysis between the user pattern of licit and illicit drugs, and associated factors

\begin{tabular}{|c|c|c|c|c|c|c|c|c|c|}
\hline \multirow{2}{*}{ Variables } & \multicolumn{3}{|c|}{ Licit drugs } & \multicolumn{3}{|c|}{ Illicit drugs } & \multicolumn{3}{|c|}{ Licit and illicit drugs } \\
\hline & $n(\%)$ & PR & $\mathbf{p}$ & n(\%) & PR & $\mathbf{p}$ & $n(\%)$ & PR & $\mathbf{p}$ \\
\hline \multicolumn{10}{|l|}{ Gender } \\
\hline Male & $32(14.1)$ & 1.0 & & $23(10.0)$ & 1.0 & & $173(75.9)$ & 1.0 & \\
\hline Female & $4(9.7)$ & 0.69 & 0.49 & $2(4.9)$ & 0.48 & 0.32 & $35(85.4)$ & 1.12 & 0.53 \\
\hline \multicolumn{10}{|l|}{ Skin color } \\
\hline Brown & $20(17.1)$ & 1.0 & & 13(11.1) & 1.0 & & $84(71.8)$ & 1.0 & \\
\hline White & $14(11.7)$ & 0.68 & 0.27 & $11(9.1)$ & 0.82 & 0.63 & $95(79.2)$ & 1.09 & 0.52 \\
\hline Black & $2(7.7)$ & 0.44 & 0.28 & $1(3.8)$ & 0.34 & 0.30 & $23(88.5)$ & 1.22 & 0.38 \\
\hline Yellow & - & - & - & - & - & - & $6(100.0)$ & 1.38 & 0.43 \\
\hline \multicolumn{10}{|l|}{ Marital status } \\
\hline Without a partner & $29(13.4)$ & 1.0 & & $22(10.1)$ & 1.0 & & $166(76.5)$ & 1.0 & \\
\hline Ith a partner & $7(13.5)$ & 1.0 & 0.98 & $3(5.8)$ & 0.56 & 0.36 & $42(80.6)$ & 1.05 & 0.75 \\
\hline \multicolumn{10}{|l|}{ Residing with } \\
\hline Family & $23(11.0)$ & 1.0 & & $22(10.5)$ & 1.0 & & $164(78.5)$ & 1.0 & \\
\hline Alone & $13(21.7)$ & 1.96 & 0.05 & $3(5.0)$ & 0.47 & 0.22 & $44(73.3)$ & 0.93 & 0.68 \\
\hline \multicolumn{10}{|l|}{ Children } \\
\hline No & $5(4.2)$ & 1.0 & & $15(12.5)$ & 1.0 & & $100(83.3)$ & 1.0 & \\
\hline Yes & $31(20.8)$ & 4.99 & - & $10(6.7)$ & 0.53 & 0.12 & $108(72.5)$ & 0.86 & 0.30 \\
\hline \multicolumn{10}{|l|}{ Religion } \\
\hline Yes & $33(14.5)$ & 1.0 & & $24(10.6)$ & 1.0 & & $170(74.9)$ & 1.0 & \\
\hline No & $15(7.1)$ & 0.49 & 0.23 & $1(2.4)$ & 0.22 & 0.14 & $38(90.5)$ & 1.20 & 0.29 \\
\hline \multicolumn{10}{|l|}{ Education (years old) } \\
\hline$>7$ & $21(12.4)$ & 1.0 & & $14(8.3)$ & 1.0 & & $134(79.3)$ & 1.0 & \\
\hline$\leq 7$ & $15(15.0)$ & 1.20 & 0.57 & $11(11.0)$ & 1.32 & 0.48 & $74(74.0)$ & 0.74 & 0.31 \\
\hline \multicolumn{10}{|l|}{ Income (MW) } \\
\hline$<4$ & $22(17.7)$ & 1.0 & & $12(9.7)$ & 1.0 & & $90(72.6)$ & 1.0 & \\
\hline $4-7$ & $8(9.7)$ & 0.54 & 0.14 & $9(11.0)$ & 1.13 & 0.77 & $65(79.3)$ & 1.09 & 0.57 \\
\hline$\geq 7$ & $5(10.0)$ & 0.56 & 0.24 & 2.0 & 0.20 & 0.13 & $44(88.0)$ & 1.21 & 0.29 \\
\hline \multicolumn{10}{|c|}{ Age when using it (years old) } \\
\hline$<18$ & $21(9.7)$ & 1.0 & & $17(7.8)$ & 1.0 & & $179(82.5)$ & 1.0 & \\
\hline$\geq 18$ & $15(29.4)$ & 3.03 & 0.00 & $8(15.7)$ & 2.00 & 0.10 & $28(54.9)$ & 0.66 & 0.04 \\
\hline
\end{tabular}

*Minimum wage (SM) valid at the time of the research: R\$ 678.00. PR = Prevalence Ratio 
The bivariate analysis was positively associated with the outcome variable "use of licit drugs": having children (PR 4.99 95\% CI 1.94-12.84) and age of onset of use $\geq 18$ years old (PR 3.03 95\% CI 1.56-5.89). Regarding the outcome "use of licit and illicit drugs," the data were negatively associated with the age of use $\geq 18$ years old (PR $0.6695 \%$ CI 0.44-0.99). In the outcome "use illicit drugs" no association was revealed.

Table 2 describes the history of use and abuse of psychoactive substances. The drug of greatest difficulty of abandonment was crack (37.6\%); The time without the use was $>180$ days $(43.6 \%)$; The 'problem' was identified by others (55.3\%); The age of onset of use was $<18$ years old $(81.2 \%)$; The first intervention was aged $\geq 24$ years old $(53.0 \%)$; And multiuser individuals prevailed (88.7\%). Regarding drug use, the highest prevalence was alcohol (70.7\%), followed by tobacco (66.5\%).

As for the demand for help, it has been subdivided into up to three times of occurrence described in Table 3.

Considering three attempts to seek help, rehabilitation clinics prevailed at all times (first: 68.8\%, second: $81.7 \%$ and third: $85.7 \%$ ).

As for the evaluation of the individuals in the interventionist actions carried out in the therapeutic communities and the Psychosocial Care Center, the most frequent actions were prayer (49.2\%), followed by therapeutic groups (26.3\%), work (9\%), medication use (8.6\%) and physical activity (7.1\%).

Regarding the influence of the professionals in the rehabilitation process, it was observed the pharmacist (87.6\%), followed by the monitor (58.3\%), the physician (50.4\%), occupational therapy (40.2\%), the nurse $(29.7 \%)$, the psychologist $(24.4 \%)$, the nursing technician $(10.9 \%)$, the physical educator $(8.6 \%)$ and the social worker $(7.9 \%)$.
Table 2 - History of use and abuse of psychoactive substances in individuals surveyed

\begin{tabular}{|c|c|c|}
\hline Variables & n (\%) & $\begin{array}{c}\text { Confidence } \\
\text { interval 95\% }\end{array}$ \\
\hline \multicolumn{3}{|c|}{ Most difficult substance to give up } \\
\hline Crack & $100(37.6)$ & $31.6-42.5$ \\
\hline Tobacco & $57(21.4)$ & $16.9-26.3$ \\
\hline Alcohol & $56(21.1)$ & $16.2-26.3$ \\
\hline Cocaine & $24(8.6)$ & $5.6-12.4$ \\
\hline Marijuana & $20(7.5)$ & $4.5-10.5$ \\
\hline None & $8(3.0)$ & $1.1-5.3$ \\
\hline Benzodiazepine & $1(0.4)$ & $0.0-1.1$ \\
\hline \multicolumn{3}{|c|}{ Time not using (days) } \\
\hline$>180$ & $116(43.6)$ & $38.0-49.2$ \\
\hline $60-180$ & $89(33.5)$ & $27.8-39.5$ \\
\hline$<60$ & $61(22.9)$ & $18.0-28.6$ \\
\hline \multicolumn{3}{|c|}{ Who identified the problem } \\
\hline Others & $147(55.3)$ & $49.2-60.9$ \\
\hline The user & $119(44.7)$ & 39.1-50.8 \\
\hline \multicolumn{3}{|c|}{ Age starting its use (years) } \\
\hline$<18$ & $216(81.2)$ & $76.3-85.7$ \\
\hline$\geq 18$ & $50(18.8)$ & $14.3-23.7$ \\
\hline \multicolumn{3}{|c|}{ Age at the first intervention (years) } \\
\hline$\leq 24$ & $141(53.0)$ & $46.8-589$ \\
\hline$\geq 25$ & $125(47.0)$ & $41.1-532$ \\
\hline \multicolumn{3}{|l|}{ Uni or multiuser } \\
\hline Multiusuer & $236(88.7)$ & $84.5-925$ \\
\hline Uni usuer & $30(11.3)$ & $7.5-155$ \\
\hline \multicolumn{3}{|c|}{ Using alcohol in their life } \\
\hline Yes & $188(70.7)$ & $65.4-75.9$ \\
\hline No & $78(29.3)$ & $24.1-346$ \\
\hline \multicolumn{3}{|l|}{ Tobacco } \\
\hline Yes & $176(66.5)$ & $60.5-718$ \\
\hline No & $90(33.5)$ & $28.2-395$ \\
\hline \multicolumn{3}{|c|}{ Using crack in their life } \\
\hline Yes & $156(58.6)$ & $52.9-643$ \\
\hline No & $110(41.4)$ & $35.7-47.4$ \\
\hline \multicolumn{3}{|c|}{ Using cocaine in their life } \\
\hline No & $139(52.3)$ & $46.2-579$ \\
\hline Yes & $127(47.7)$ & $42.1-538$ \\
\hline \multicolumn{3}{|c|}{ Using marijuana in their life } \\
\hline No & $185(69.5)$ & $63.9-748$ \\
\hline Yes & $81(30.5)$ & $25.2-36.1$ \\
\hline
\end{tabular}


Table 3 - Prevalence of demand for help among individuals in use and abuse of tobacco, alcohol and other drugs

\begin{tabular}{lcc}
\hline Search for help & n (\%) & CI95\% \\
\hline First search for help & & \\
Rehabilitation clinics & $183(68.8)$ & $63.2-74.8$ \\
Psychosocial Care Center/open clinics & $70(26.3)$ & $20.7-31.6$ \\
Own initiative & $13(4.9)$ & $2.3-7.9$ \\
Second search for help & & \\
Rehabilitation clinics & $147(81.7)^{*}$ & $75.6-87.2$ \\
Psychosocial Care Center/open clinics & $30(16.7)^{*}$ & $11.1-22.2$ \\
Own initiative & $3(1.7)^{*}$ & $0.0-3.9$ \\
Third search for help & & \\
Rehabilitation clinics & $96(85.7)^{*}$ & $79.5-92.0$ \\
Psychosocial Care Center/open clinics & $16(14.3)^{*}$ & $8.0-20.5$ \\
\hline *Number of valid answers to the question. CI: $95 \%$ confidence interval
\end{tabular}

\section{Discussion}

The limitations of this study are the type of cross-sectional, descriptive and convenience survey in a specific reality, which does not allow population generalizations and incidence estimates of issues related to the problem of alcohol and other drug abuse. However, it is believed to have contributed to the knowledge of the context of extreme relevance, besides being a matter of concern in Brazil and the world, for public health.

The highest prevalence of drug use in this study was among males, supported by other studies ${ }^{(10-14)}$. However, the problem should not be neglected without covering the female, that is, although the higher prevalence reaches men, women show an increase in rates of alcohol and other drug use, a cause of concern for researchers who study the pattern of female consumption of psychoactive substances ${ }^{(10,12-13,15)}$.

Corroborating with the findings of this study, the current socio-demographic profile of individuals who abuse drugs prevails among single individuals, with low education and monthly income, and living with the family. These aspects become a potential risk for biased vulnerability to alcohol and drug consumption in society ${ }^{(14)}$.
In this study, the positive association between the outcome variable "use of licit drugs" to have children was a risk factor for drug use. An innovative fact, since no research was found showing this variable for discussion. On the other hand, it was found in another study that having family was a protective factor for non-use of the drug( ${ }^{(16)}$. Regarding the outcome "use of licit and illicit drugs," the age factor ( $\geq 18$ years old) remained associated. This diverges when compared to another study in which initiation was between 14-19 years old ${ }^{(14)}$.

Another characteristic of the drug user population is concentrated in a young age group, with a mean age of 20 to 24 years old ${ }^{(14)}$. For alcohol use, there is a higher prevalence in the age group $>30$ years old ${ }^{(13)}$. As for the beginning of consumption, especially of illicit drugs, initiation occurs between $\geq 14$ years old and 15-19 years old ${ }^{(14)}$. A European study shows that about 2.2 million young adults between 15 and 34 years old have used cocaine in the last year, which is also the most commonly used illicit drug in Europe ${ }^{(17)}$.

Regarding the use of licit and illicit substances, alcohol, tobacco, and crack were the most prevalent in this study, being the majority multiuser, corroborating with other findings ${ }^{(12-13)}$.

The variable religiosity is described as protective for the use of alcohol, which consequently may restrict the use of other drugs. Prayer has proved to be a relevant method or one that is most practiced in the context of rehabilitation. In this sense, attending churches influences the recovery of individuals beneficially ${ }^{(10)}$.

So prevalent as to prayer were group activities, which are close to psychoeducation. Through actions that aim at self-expression, motor and social activities provide a better understanding of subjectivity, allowing the stimulation of creativity, skill, and autonomy ${ }^{(18)}$.

Regarding the demand for seeking help" care, most of them occurred in specialized private rehabilitation clinics. Even considering that the collection of data took place mostly in clinics, the living of the indi- 
vidual who initially mobilized for these spaces in the search for help is worthy. These places grew rapidly in Brazil, due to the insufficiency of the public health system to the complex subject of abuse of alcohol and other drugs. Although the term "therapeutic community" is used, these treatment spaces are not aligned with the idealized by the Psychiatric Reform Movements, because they have antagonistic principles. The activities developed in these clinics are characterized by social isolation, and abstinence has been the only resource for recovering the person who uses alcohol and other psychoactive drugs ${ }^{(8)}$.

The Therapeutic Communities remain for more than 30 years in the Brazilian context welcoming individuals who use drugs. From a survey carried out in partnership with the Secretary of Policy on Drugs, with governmental and non-governmental institutions in the attention to the user of alcohol and other drugs, 439 (35.0\%) of the 1,256 of the institutions are named Therapeutic Communities ${ }^{(19)}$. However, they do not implement practices stimulated by public health policies, since they do not meet the psychosocial model adopted by the Unified Health System ${ }^{(8)}$.

In other realities, the demand for treatment occurs in Psychosocial Care Centers of Alcohol and Drugs; institutions specialized in the care of alcohol dependence and other drugs ${ }^{(14-15)}$. These health action services are public and target practices guided by harm reduction policies, which aim to reduce the harmful effects of psychoactive substance use among users. In other words, there is the elaboration of a unique therapeutic project, aiming at health promotion, protection, and projection of mechanisms to cope with problems caused by alcohol and/or drug abuse ${ }^{(5-6)}$.

Considering the professionals in the study sites and their positive or negative influences on the process of rehabilitation of the individuals, a multidisciplinary team was observed, emphasizing the pharmacist, the doctor and the monitor. This data can be understood when in the literature the multidisciplinary team is part of the rehabilitation treatment of patients ${ }^{(14-15,18)}$. It is worth emphasizing that these professionals should stimulate the construction of an expanded view of the complexity of alcohol and other drug abuse and, consequently, a higher quality of healthcare $^{(14-15)}$.

\section{Conclusion}

In the search for therapeutic help, the male gender predominated, emerging a reality with the absence of effective public care to this population, highlighting the private network. It was identified that these people are multiusers, search for these spaces repeatedly, denoting the precarious resolution of the treatments available in the private sector and the public network. The pharmaceutical professional was the one that most influenced the users in the process of rehabilitation.

\section{Collaborations}

Leandro BRC, Monteiro LHB, Vera I, Felipe RL and Fernandes IL contributed in the analysis and interpretation of the data, writing of the article and approval of the final version to be published. Lucchese $\mathrm{R}$ contributed to the project design, critical review relevant intellectual content and final approval of the version to be published.

\section{References}

1. United Nations Office on Drugs and Crime. World drug report. New York: United Nations; 2014.

2. Zaridze D, Lewington S, Boroda A, Scélo G, Karpov $\mathrm{R}$, Lazarev A, et al. Alcohol and mortality in Russia: prospective observational study of 151000 adults. Lancet. 2014; 383(9927):1465-73.

3. Instituto Nacional de Ciências e Tecnologia para Políticas Públicas do Álcool e outras Drogas (BR). II Levantamento Nacional de Álcool e Drogas [Internet]. 2012[citado 2016 ago. 9]. Disponível em: http://inpad.org.br/lenad/resultados/ 
4. Running Bear U, Anderson H, Manson SM, Shore JH, Prochazka AV, Novins DK. Impact of adaptive functioning on readmission to alcohol detoxification among Alaska Native People. Drug Alcohol Depend [Internet]. 2014 [cited 2017 Jan 13];140:168-74. Availbale from: http:// www.sciencedirect.com/science/article/pii/ S0376871614008448

5. Kuo M, Shamsian A, Tzemis D, Buxton JA. A drug use survey among clients of harm reduction sites across British Columbia, Canada, 2012. Harm Reduct J [Internet]. 2014 [cited 2017 Jan 13]; 11:13. Availbale from: https://www.ncbi.nlm.nih. gov/pmc/articles/PMC4016659/

6. Mackey TK, Werb D, Beletsky L, Rangel G, Arredondo J, Strathdee SA. Mexico's "ley de narcomenudeo" drug policy reform and the international drug control regime. Harm Reduct J. 2014; 11(31):1-7.

7. Lee MT, Horgan CM, Garnick DW, Acevedo A, Panas L, Ritter GA, et al. A performance measure for continuity of care after detoxification: Relationship with outcomes. J Subst Abuse Treat. 2014; 47(2):130-9.

8. Perrone PA. A comunidade terapêutica para recuperação da dependência do álcool e outras drogas no Brasil: mão ou contramão da reforma psiquiátrica? Ciênc Saúde Coletiva. 2014; 19(2):569-80.

9. Alves VS, Lima IMSO. Atenção à saúde de usuários de álcool e outras drogas no Brasil: convergência entre a saúde pública e os direitos humanos. RDisan. 2013;13(3):9-32.

10. Borders TF, Booth BM. Stimulant use, religiosity, and the odds of developing or maintaining an alcohol use disorder over time. J Stud Alcohol Drugs. 2013; 74(3):369-77.

11. Gage SH, Hickman M, Heron J, Munafò MR, Lewis G, Macleod J,et al. Associations of cannabis and cigarette use with depression and anxiety at age 18: findings from the Avon Longitudinal Study of Parents and Children. PLoS One [Internet]. 2015 [cited 2017 Jan 13];10(4):e0122896. Available from: http://journals.plos.org/plosone/ article?id=10.1371/journal.pone.0122896
12. Kim JH, Martins SS, Shmulewitz D, Santaella J, Wall MM, Keyes KM, et al. Childhood maltreatment, stressful life events, and alcohol craving in adult drinkers. Alcohol Clin Exp Res. 2014; 38(7):204855 .

13. Gupta S, Sarpal SS, Kumar D, Kaur T, Arora S. Prevalence, pattern and familial effects of substance use among the male college students - a north Indian study. J ClinDiagn Res. 2013; $7(8): 1632-6$.

14. Silva CC, Costa MC, Carvalho MC, Amaral MT, Cruz NL, Silva MR. Iniciação e consumo de substâncias psicoativas entre adolescentes e adultos jovens de Centro de Atenção Psicossocial Antidrogas/ Centro de Atenção Psicossocial-AD. Ciênc Saúde Coletiva. 2014; 19(3):737-45.

15. Vargas D, Bittencourt MN, Rocha F, Oliveira MA. Representação social de enfermeiros de centros de atenção psicossocial em álcool e drogas sobre o dependente químico. Esc Anna Nery. 2013; 17(2):242-8.

16. Malta DC, Oliveira-Campos M, Prado RR, Andrade SSC, Mello FCM, Dias AJR, et al. Uso de substâncias psicoativas, contexto familiar e saúde mental em adolescentes brasileiros, Pesquisa Nacional de Saúde dos Escolares (PeNSE 2012). Rev Bras Epidemiol. 2014; (suppl):46-61.

17. European Monitoring Centre for Drugs and Drug Addiction. European Drug Report: Trends and developments. Luxembourg: Publications Office of the European Union; 2014.

18. Benevides DS, Pinto AG, Cavalcante CM, Bessa Jorge MS. Cuidado em saúde mental por meio de grupos terapêuticos de um hospital-dia: perspectivas dos trabalhadores de saúde. Interface. 2010; 14(32):127-38.

19. Melo MP, Corradi-Webster CM. Análise do funcionamento de comunidade terapêutica para usuários de drogas. Athenea Digital. 2016; 169(3):379-99. 